\title{
Performance and nutrient utilisation of dairy cows offered silages produced from three successive harvests of either a red clover-perennial ryegrass sward or a perennial ryegrass sward
}

\author{
D.J. Johnston ${ }^{1,2 \dagger}$, A.S. Laidlaw ${ }^{1}$, K. Theodoridou², C.P. Ferris ${ }^{1}$
}

${ }^{1}$ Agri-Food and Biosciences Institute, Sustainable Agri-Food Sciences Division, Large Park, Hillsborough, County Down, Northern Ireland, BT26 6DR, UK

${ }^{2}$ Queens University Belfast, University Road, Belfast, Northern Ireland, BT7 1NN, UK

Abstract

The need to reduce reliance on imported protein feeds within the UK and Ireland has stimulated interest in locally grown forage legume crops, including red clover (Trifolium pratense L.). This 13-wk study examined the performance of 28 dairy cows offered silages produced from three successive harvests $(H)$ of either a pure grass sward (GS) receiving $315 \mathrm{~kg} \mathrm{~N} / \mathrm{ha}$ per annum or a red clover-perennial ryegrass sward (RCGS) receiving $22 \mathrm{~kg} \mathrm{N/ha} \mathrm{per} \mathrm{annum.}$ The crops of H1, $\mathrm{H} 2$ and $\mathrm{H} 3$ were wilted for 48,72 and $72 \mathrm{~h}$, respectively. Silages from H1, H2 and H3 were offered for 5,5 and 3 wk, respectively, with cows supplemented with $8.0 \mathrm{~kg}$ concentrate/d throughout the experiment. Digestibility of DM and the effectively degradable protein content were lower, while protein degradability was higher, for RCGS than for GS. Silage DM intakes (DMIs) were higher for RCGS than for GS at H1 and H2, with no differences at H3. Milk yield was higher with RCGS than with GS at H3, with no differences at H1 and H2. Milk fat and milk protein contents were lower with RCGS than with GS at H3 but did not differ at H1 and H2. Faecal N/N intake was higher in the RCGS group than in the GS group at H1, with no differences at $\mathrm{H} 2$ and $\mathrm{H} 3$. Gross energy digestibility was lower for RCGS than for GS at H2. Although cow performance was higher with RCGS treatment, the responses were variable between harvests, largely reflecting the changing proportion of $R C$ in the swards as the season progressed.

Keywords

Dairy cow $\bullet$ forage $\cdot$ grass silage $\bullet$ legume $\cdot$ red clover $\bullet$ sustainability

\section{Introduction}

Within the United Kingdom (UK) and Ireland, the protein requirement of higher-yielding dairy cows is normally met, in part, through the use of imported protein feeds, including soybean meal and rapeseed meal. However, supply and price volatility, as well as restrictions on the use of genetically modified feeds, have created renewed interest in the use of forage legumes. In addition to their potential to produce high annual yields of dry matter (DM) and crude protein (CP), their ability to fix atmospheric nitrogen $(N)$ reduces the need for $\mathrm{N}$ fertiliser, and this can contribute to legume-based systems having a lower carbon footprint (Peyraud et al., 2009).

Red clover (Trifolium pratense L.) is a forage legume of particular interest within the UK and Ireland (Wilkins \& Jones, 2000), where it has the potential to produce high annual DM yields (Dale et al., 2014; Clavin et al., 2017). In addition, red clover silage normally has a higher protein content than grass silage (GS) (Dewhurst et al., 2003a). While the protein in red clover may degrade relatively quickly (Dewhurst et al.,
2009), the variable presence of polyphenol oxidase (PPO) in red clover can contribute to a lower rate of ruminal protein degradation compared to protein in other forage legumes, such as lucerne (Lee et al., 2004). However, due to its high protein content and the associated reduction in $\mathrm{N}$ use efficiency (Dewhurst et al., 2003a; Moorby et al., 2009), red clover silage is often offered in mixtures with GS.

In general, when dairy cows are offered either GS alone or a mixture of red clover silage and GS, the DM intake (DMI) of cows that were offered the mixture increases, with this being often associated with an increase in milk yield, while milk fat and protein content are normally either unaffected or decline (Dewhurst, 2013). However, in the majority of these studies, the GS has been produced from swards that have received moderate or high rates of $\mathrm{N}$ fertiliser, and this does not simulate silage produced from mixed swards of grass and red clover, which normally receive either none or only small amounts of $\mathrm{N}$ fertiliser. For example, the grass in a grass-red 
clover sward will have a low $\mathrm{N}$ content due to the relatively low amount of $\mathrm{N}$ transferred from red clover to the accompanying grass, particularly in the first full harvest year (Dahlin \& Stenberg, 2010).

Mixed swards of grass and red clover are often sown on farms in an attempt to increase herbage DM yields, reduce the use of inorganic fertiliser $\mathrm{N}$ and increase the nutritive value of the silage produced. In one of the few studies examining their use, Vanhatalo et al. (2006) found that cows that were offered grass-red clover silage had higher milk yields than, but similar contents of DMI, milk fat and milk protein as, cows offered GS. Nevertheless, as in most red clover feeding studies, the silages offered were produced from a single harvest, rather than from successive harvests. In contrast, on commercial dairy farms, silages produced from all harvests within a season are normally offered to livestock, and thus it is important to quantify differences between harvests within a full growing season. This is important as changes in sward structure, maturity and fibre content of the component species in a grass-red clover sward over the course of the growing season will affect the nutritional quality and intake characteristics of the silage and, consequently, milk production and milk composition (Vanhatalo et al., 2009). For example, a regrowth of a grass-red clover sward had a higher CP content and total complement of amino acids than its primary growth (Naadland et al., 2016).

The impact of offering red clover silage to dairy cows does not appear to have been examined previously on the island of Ireland. This is important as research carried out elsewhere may not be directly applicable to Ireland as the maritime climate can lead to unavoidable high humidity or rainfall at harvest, creating sub-optimal conditions for wilting (McEniry et al., 2013), which will affect the silage quality. Consequently, this study was conducted under Irish conditions, and it compared the effects of offering dairy cows grass silage and grass-red clover silages produced from three consecutive harvests over a full production year (harvested in early summer, late summer and autumn) on $\mathrm{N}$ and energy utilisation and subsequent animal performance.

\section{Materials and methods}

This study was conducted at the Agri-Food and Biosciences Institute (AFBI), Hillsborough, Northern Ireland $\left(54^{\circ} 27^{\prime} \mathrm{N}\right.$; $06^{\circ} 04^{\prime} \mathrm{W}$ ). All experimental procedures were conducted under an experimental licence granted by the Department of Health, Social Services \& Public Safety for Northern Ireland in accordance with the Animals (Scientific Procedures) Act 1986.

\section{Experimental forages}

A perennial ryegrass sward and a red clover-perennial ryegrass mixed sward (approximately 3 ha each) were established during the autumn of 2013. On 3 and 4
September 2013, crops were sown following conventional seedbed preparation using an air seed drill with a mounted spring harrow attachment (Stocks ASg, Cambs, UK; Twose, Ludlow, UK). Seeding rates for red clover ( $c v$. Merviot) and perennial ryegrass ( $\mathrm{cv}$. Navan) in the mixed sward were $9.9 \mathrm{~kg} / \mathrm{ha}$ and $22.2 \mathrm{~kg} / \mathrm{ha}$, respectively, while the seeding rate for the perennial ryegrass in the pure sward was $32.1 \mathrm{~kg} / \mathrm{ha}$. Neither sward received $\mathrm{N}$ fertiliser during establishment. The crops were harvested on three occasions in 2014, namely, 12 June $(\mathrm{H} 1), 7$ August $(\mathrm{H} 2)$ and 2 October $(\mathrm{H} 3)$. Crops were mown at approximately 14:00 $\mathrm{h}$ at each harvest using a mower-conditioner unit (Claas, Bury St Edmunds, UK) and allowed to wilt in the swaths for periods of 48,72 and $72 \mathrm{~h}$, for $\mathrm{H} 1, \mathrm{H} 2$ and $\mathrm{H} 3$, respectively, with the objective of achieving a herbage DM concentration of approximately $270-280 \mathrm{~g} /$ $\mathrm{kg}$ DM. Swards were placed in windrows using a trailed tractor-driven twin-rotor rower (Claas, Bury St Edmunds, UK) $2-3 \mathrm{~h}$ prior to ensilage and subsequently baled using a conventional round baler set at $90 \%$ density (Krone, Leeds, UK). The crops were then wrapped using a conventional bale wrapper (McHale, Mayo, Ireland), dispensing plastic film with 17 wraps per bale; each load of bales was weighed on a commercial weighbridge (capacity: $50 \mathrm{t}, \pm 10 \mathrm{~kg}$ ) before being stacked. Four samples of each herbage type were collected from the swards immediately in front of the bailer, with these subsequently dried at $85^{\circ} \mathrm{C}$ for $24 \mathrm{~h}$ to determine oven DM (ODM) content. The yields from $\mathrm{H} 1, \mathrm{H} 2$ and $\mathrm{H} 3$ for the red clover-GS (RCGS) swards were 4.4, 4.0 and $1.6 \mathrm{t} \mathrm{DM} / \mathrm{ha}$, respectively, representing an annual yield of $10.0 \mathrm{t} \mathrm{DM} / \mathrm{ha}$. The yields from $\mathrm{H} 1, \mathrm{H} 2$ and $\mathrm{H} 3$ for the GS swards were 5.2 , 3.4 and $1.8 \mathrm{t} \mathrm{DM} / \mathrm{ha}$, respectively, representing an annual yield of $10.4 \mathrm{t} \mathrm{DM} / \mathrm{ha}$. Based on visual assessment before mowing, the RCGS swards were estimated to contain approximately $20 \%, 40 \%$ and $60 \%$ red clover at each of the harvests $\mathrm{H} 1, \mathrm{H} 2$ and $\mathrm{H} 3$, respectively.

In March 2014, both the GS and the RCGS swards received $22 \mathrm{~kg} \mathrm{~N} / \mathrm{ha}$ (urea: $46 \% \mathrm{~N}$ ). The GS sward received a further $106 \mathrm{~kg} \mathrm{~N} / \mathrm{ha}$ (calcium ammonium nitrate: $27 \% \mathrm{~N}$ ) in April, followed by $122 \mathrm{~kg} \mathrm{~N} / \mathrm{ha}$ after $\mathrm{H} 1$ in June and a final application of $65 \mathrm{~kg} \mathrm{~N} / \mathrm{ha}$ in August following H2. The RCGS sward received no additional $\mathrm{N}$ fertiliser during the growing season.

\section{Animals and housing}

Twenty-eight three-way cross (Swedish-Red $\times$ Jersey/ Holstein-Friesian) dairy cows (22 multiparous, six primiparous), with a mean lactation number of 3.1 and mean days-in-milk of $82 \mathrm{~d}$ (s.d., $7.8 \mathrm{~d}$ ), were used in this experiment. Cows were housed as a single group in a free-stall house with concrete flooring with access to individual cubicles that were fitted with rubber mats, and they were bedded with sawdust twice daily. The cubicle-to-cow ratio was 1:1 at all times, thus meeting the recommendations of the Farm Animal Welfare Committee 
(FAWC, 1997). The floor area was scraped every $3 \mathrm{~h}$ using an automated system.

\section{Treatments}

During a 2-wk pre-experimental period, cows were offered GS plus $8.0 \mathrm{~kg} / \mathrm{d}$ of concentrate via an in-parlour concentratefeeding system. Cows were allocated to one of two experimental treatments (GS or RCGS) on the final day of the pre-experimental period, with cows within each treatment group balanced for parity (1, 2, 3 and 4) and days in milk; milk yield, milk fat and protein content; live weight (LW); and body condition score (BCS) during the week prior to the start of the study. Throughout the experiment, all cows were offered $8.0 \mathrm{~kg} / \mathrm{d}$ of a common concentrate through an in-parlour concentrate-feeding system. This was divided into two equal meals, $4.0 \mathrm{~kg}$ at each milking. The ingredient composition of the concentrate (in grams per kilogram, fresh basis) was as follows: maize meal, 171; soya bean meal, 132; wheat, 128; rapeseed meal, 125; corn gluten, 124; soya hulls, 101; palm kernel, 99; wheat feed, 45; molaferm (United Molasses, Belfast, UK), 40; lime flour, 9.5; palm oil, 9.5; salt, 8.2; calcined magnesite, 4.1; mineral-vitamin mix, 4; yeast (Actisaf, Lesaffre, Shannon, Ireland), 0.5.

Cows were offered the experimental forages for a 13-wk experimental period. Silages produced from $\mathrm{H} 1, \mathrm{H} 2$ and $\mathrm{H} 3$ were offered successively, for periods of 5,5 and $3 \mathrm{wk}$, respectively, with the duration of each period broadly reflecting the yields within each harvest of the RCGS sward. Fresh silage was offered daily at approximately $09: 00 \mathrm{~h}$ (at $107 \%$ of the previous day's fresh weight intake), with uneaten silage removed the following day at approximately 08:00 h. Silage for cows for each treatment was mixed in a feeder wagon (Redrock Vari-Cut-12, Redrock, Armagh, Northern Ireland) for approximately $6 \mathrm{~min}$ prior to being deposited in a series of feed boxes mounted on weigh scales. Cows accessed silage in these feed boxes via Calan gates (American Calan Inc., Northwood, NH, USA) linked to an electronic identification system, thus enabling individual cow intakes to be recorded daily. Cows had free access to fresh water at all times.

\section{Cow measurements and sampling of feeds offered}

All cows were milked twice daily (between 06:00 and 08:00 h; and between 15:00 and 17:00 h) throughout the experiment using a 50-point rotary milking parlour (Boumatic, Madison, WI, USA), with milk yields automatically recorded at each milking, and the total daily milk yield for each cow for each 24-h period was calculated. Milk samples were taken during two consecutive milkings each week throughout the experiment and analysed for fat, protein and lactose concentrations using an infrared milk analyser (Milkoscan Model 605; Foss Electric, Warrington, UK). A weighted concentration of each constituent was determined for the 24-h sampling period.
LW was recorded twice daily (immediately after each milking) using an automated weighbridge (BioControl, Rakkestad, Norway), and the mean weekly LW for each cow was determined. The BCS of each cow was estimated fortnightly on a 1-5 scale, according to Edmonson et al. (1989), by a trained technician.

Samples of the experimental silages were taken daily throughout the experiment, dried at $85^{\circ} \mathrm{C}$ for $24 \mathrm{~h}$ to determine the ODM content and milled through a mesh sieve with $1-\mathrm{mm}$ apertures. Sub-samples of the dried milled silages were taken twice weekly and bulked for each week, with the bulked samples analysed for neutral detergent fibre (NDF), acid detergent fibre (ADF) and ash concentrations. A fresh sample of each batch of silage was taken weekly and analysed for the following: concentrations of $\mathrm{N}$, ammonia- $\mathrm{N}$, gross energy (GE), fermentation acids (lactic, acetic, propionic, n-butyric and isovaleric acids), ethanol, propanol, metabolisable energy (ME), and $\mathrm{pH}$. The concentrate offered was sampled 3 times weekly, with one sub-sample dried at $85^{\circ} \mathrm{C}$ for $24 \mathrm{~h}$ for determination of ODM content and the dried sample, discarded. A second sub-sample was dried at $60^{\circ} \mathrm{C}$ for $48 \mathrm{~h}$ prior to milling through a 1-mm sieve, bulked for each 14-d period, and analysed for N, NDF, ADF, ash, GE and starch concentrations.

\section{Nutrient utilisation}

During the final $8 \mathrm{~d}$ of the feeding period within each harvest, four cows from each treatment (the same four cows at each harvest) were used in a nutrient utilisation study. The four cows selected from each treatment group were initially balanced for daily milk yield and LW. All eight cows were transferred into an experimental nutrient utilisation facility (at approximately 09:00 h) and housed in individual stalls, with their lying area comprising a rubber mat. Cows continued to be offered their experimental rations in a feed box located at the front of each stall. The experimental silages were offered ad libitum daily at 09:00 h, while uneaten silage was removed, with refused feed weighed and recorded the following day at 08:00 h. Concentrate $(8.0 \mathrm{~kg} / \mathrm{d})$ was offered in two equal meals each day $(4.0 \mathrm{~kg} / \mathrm{meal})$ at $06: 30 \mathrm{~h}$ and $16: 30 \mathrm{~h}$, during milking. This concentrate was offered in plastic feed buckets, which were placed within the feed boxes, and removed after all the concentrates had been consumed at each feeding time. Cows had access to fresh water at all times via a drinker located within each stall. Cows were weighed prior to and on completion of each balance period, with the average LW used in energy utilisation calculations.

Measurements of nutrient utilisation commenced $24 \mathrm{~h}$ after cows were placed in the nutrient utilisation facility and comprised a $6-\mathrm{d}$ feeding period (commencing $2 \mathrm{~d}$ before the first collection of faeces and urine) and a 6-d total faeces and urine collection period. Faeces were collected in a plastic 
collection tray $(96 \mathrm{~cm} \times 108 \mathrm{~cm} \times 36 \mathrm{~cm})$ placed behind each cow. Urine was collected in a $25-\mathrm{L}$ plastic container via a flexible plastic tube, which was attached to a urine separation system. This was held in position over the vulva by attaching it using Velcro fasteners to a "patch" (Bostik, France) glued on either side of the cow's tail head. Approximately $300 \mathrm{~mL}$ of $50 \%$ sulphuric acid was added to each urine collection container when empty to minimise $\mathrm{N}$ losses as ammonia. Containers were examined at approximately $20: 00 \mathrm{~h}$ and, if $>60 \%$ full approximately, were replaced with an empty container. The total weight of faeces and urine produced during each $24-\mathrm{h}$ collection period was recorded, and a sample of each (0.05 by weight) was retained for subsequent analysis. Faeces and urine samples were stored in a fridge $\left(4^{\circ} \mathrm{C}-6^{\circ} \mathrm{C}\right)$ until the final day of the collection period, when the six daily faeces samples and six daily urine samples from each cow were bulked. The single bulked fresh urine sample for each cow was analysed for GE and $\mathrm{N}$ concentrations, while the single bulked fresh faeces sample for each cow was analysed for $\mathrm{N}$ concentration. A single bulked dried faeces sample for each cow was dried at $85^{\circ} \mathrm{C}$ for $100 \mathrm{~h}$ to determine the ODM, with the dried sample subsequently milled and analysed for ADF, NDF, ash and GE concentrations. A milk sample was taken at each milking, bulked in proportion to yield, with samples bulked for the entire 6-d period and subsequently analysed for $\mathrm{GE}$ and $\mathrm{N}$ concentrations. Fresh silages offered were analysed daily for ODM, GE and $\mathrm{N}$ concentrations, while daily dried samples over the 6-d nutrient utilisation period were bulked and the single bulked sample for each period analysed for ADF, NDF and ash concentrations. The concentrate offered was sampled daily, bulked for the 6-d nutrient utilisation period and its ODM concentration determined. The dry samples were subsequently analysed for GE, NDF, ADF, N and ash concentrations.

\section{In vitro protein degradation kinetics using the Daisy" incubator}

Samples of the dry milled silages collected twice weekly were bulked for each harvest and used to determine in vitro ruminal protein degradability using an ANKOM Daisy" incubator (Ankom Technology ${ }^{\circledR}$, Macedon, NY, USA). Samples (0.5 g) were weighed into F57 filter bags (in triplicate) (which had been pre-rinsed in acetone and allowed to dry) and then heat sealed. The four Daisy jars (2-L capacity) were filled with a warmed $\left(39^{\circ} \mathrm{C}\right)$ mixture of solutions $\mathrm{A}(266 \mathrm{~mL})$ and $B(1,330 \mathrm{~mL})$ (1:5 v/v; $\mathrm{pH} 6.8)$. The reagents used were as follows: solution A (in $1 \mathrm{~L}$ of deionised water), $\mathrm{KH}_{2} \mathrm{PO}_{4}(10.0 \mathrm{~g}), \mathrm{MgSO}_{4} \cdot 7 \mathrm{H}_{2} \mathrm{O}$ $(0.5 \mathrm{~g}), \mathrm{NaCl}(0.5 \mathrm{~g}), \mathrm{CaCl}_{2} \cdot 2 \mathrm{H}_{2} \mathrm{O}(0.1 \mathrm{~g})$ and urea $(0.5 \mathrm{~g})$; solution $\mathrm{B}$ (in $100 \mathrm{~mL}$ of deionised water), $\mathrm{Na}_{2} \mathrm{CO}_{3}(15.0 \mathrm{~g}$ ) and $\mathrm{Nsga}_{2} \mathrm{~S} \cdot 9 \mathrm{H}_{2} \mathrm{O}(1.0 \mathrm{~g})$. Rumen fluid was then used to inoculate each Daisy jar. The rumen fluid used was collected $3 \mathrm{~h}$ after morning feeding from two Holstein cows fitted with a ruminal cannula, thoroughly mixed together and poured into an insulated bottle prior to transport to the laboratory, where it was then filtered through four layers of cheese cloth. The rumen fluid was then poured into the Daisy jars $(400 \mathrm{~mL} /$ jar), mixed with solution $A$ and $B$ and the inoculum was again warmed to $39^{\circ} \mathrm{C}$. The jars were continuously purged with a stream of $\mathrm{CO}_{2}$ gas to maintain anaerobic conditions.

The in vitro ruminal protein degradation kinetics were studied for each silage type and harvest according to the "gradual addition/all out" schedule (Theodoridou \& Yu, 2013), with samples incubated in the jars for 2, 4, 8, 12, 24 and $48 \mathrm{~h}$. The bags assigned to the 48 -h incubation period were inserted first, followed $24 \mathrm{~h}$ later by those assigned to the $24-\mathrm{h}$ period, with this step repeated for the remaining bags at the appropriate time intervals. Each treatment was contained within separate jars and not mixed with other treatments. The whole process comprised three experimental runs. The number of bags for each treatment and in each experimental run were 2, 2, 2, 2, 6, 4 and 5 for incubation times $0,2,4,8,16,24$ and $48 \mathrm{~h}$, respectively. The maximum number of bags in each jar at any one time point was 23 .

The jars were rotated continuously in the incubation chamber of the Daisy" incubator, and mounted on slow-turning rollers inside the fermentation cabinet, which results in vessel rotation and filtering. After the incubation, the bags were removed from the incubator and rinsed under a cold stream of tap water without detergent to remove excess rumen contents and subsequently dried at $55^{\circ} \mathrm{C}$ for $48 \mathrm{~h}$ and re-weighed. The soluble $\mathrm{N}$ fraction was determined by soaking the bags containing the ground samples in warm water $\left(40^{\circ} \mathrm{C}\right)$ for $1.5 \mathrm{~h}$ and was considered as the proportion of sample $\mathrm{N}$ that had disappeared from the bags at $T 0$. The dried samples were kept in a refrigerated room $\left(4^{\circ} \mathrm{C}\right)$. Within each treatment, samples from each harvest were subsequently bulked and milled through a 1-mm sieve and analysed for $\mathrm{N}$ using the Dumas method (Elementar, Vario Max CN).

\section{Rumen degradation kinetics}

In vitro rumen degradation kinetics of $\mathrm{CP}$ were determined using the first-order kinetics equation described by Ørskov and McDonald (1979) and modified by Robinson et al. (1986) and Dhanoa (1988) to include lag time:

$$
R(t)=U+(100-S-U) \times \exp [-K \mathrm{~d}(t-T 0)]
$$

where $R(t)$ is the residue present at $t \mathrm{~h}$ incubation (\%); $S$ is the soluble fraction (\%); $U$ is the undegradable fraction (\%); $D$ is the potentially degradable fraction (\%); $T 0$ is the lag time (h); and $K \mathrm{~d}$ is the degradation rate $(\% / \mathrm{h})$.

The results were calculated using the NLIN (non-linear) procedure of SAS (SAS Institute, Cary, NC, USA), with iterative least-squares regression (Gauss-Newton method). 
Based on the non-linear parameters estimated by Equation 1 ( $S, U$ and $K d$ ), rumen-degraded feed $C P$ (RDP) and rumen undegraded $\mathrm{CP}(\mathrm{RUCP})$ were predicted according to the NRC 2001 model as follows:

$$
\begin{aligned}
& \operatorname{RDP}(\%)=S+(D \times K \mathrm{~d}) /(K \mathrm{p}+K \mathrm{~d}), \\
& \operatorname{RUP}(\%)=U+(D \times K \mathrm{~d}) /(K \mathrm{p}+K \mathrm{~d}),
\end{aligned}
$$

where $D=100-S-U(\%)$ and $K p$ is the estimated rate of outflow of digesta from the rumen (\%), which was assumed to be $0.06 / \mathrm{h}$, according to Tamminga et al. (1994).

\section{Estimation of the intestinal digestibility of RUCP}

Intestinal digestibility of feed RUCP was determined according to the protocol for ruminants (Calamiglia \& Stern, 1995). Dried ground rumen residues, containing $15 \mathrm{mg}$ of $\mathrm{N}$, after $16 \mathrm{~h}$ of ruminal incubation, were exposed for $1 \mathrm{~h}$ to $10 \mathrm{~mL}$ of $0.05 \mathrm{~mol} / \mathrm{L} \mathrm{HCl}$ solution containing $1 \mathrm{~g} / \mathrm{L}$ pepsin. The $\mathrm{pH}$ was then neutralised with $0.5 \mathrm{~mL}$ of $0.5 \mathrm{~mol} / \mathrm{L} \mathrm{NaOH}$ and $13.5 \mathrm{~mL}$ of $\mathrm{pH} 7.8$ phosphate buffer containing $37.5 \mathrm{mg}$ of pancreatin, which were subsequently incubated at $38^{\circ} \mathrm{C}$ for $24 \mathrm{~h}$. After $24 \mathrm{~h}$ incubation, $3 \mathrm{~mL}$ of a $100 \%(\mathrm{wt} / \mathrm{vol})$ trichloroacetic acid (TCA) solution was added to precipitate the undigested proteins. The samples were centrifuged, and the supernatant was analysed for $\mathrm{N}$ by the Kjeldahl method (Tecator Kjeltec Auto 2400/2460 Analyzer/Sampler System, Foss). Intestinal digestion of protein was calculated as TCA-soluble $\mathrm{N}$ divided by the amount of $\mathrm{N}$ in the 16 -h residue sample.

\section{Chemical analysis of feed, faeces and urine samples obtained during the study}

Nitrogen concentrations of fresh samples were determined using the Kjeldahl method, while $\mathrm{N}$ concentrations of dried samples were determined using the Dumas method (Elementar, Vario Max CN). Concentrations of NDF and ADF were determined using a Fibertec analyser (Fibertec FT122; Foss, Hillerød, Denmark) based on the method of Van Soest (1976). Ash concentrations were determined following combustion in a muffle furnace at $550^{\circ} \mathrm{C}$ for approximately $10 \mathrm{~h}$. Starch concentrations were determined using a Megazyme Kit (Megazyme International, Bray, Ireland). GE concentrations of fresh silage, dry concentrate and faeces, and of freeze-dried samples of milk and urine, were determined using a bomb calorimeter (Parr 6400 Bomb Calorimeter; Parr Instrument Co., Moline, IL, USA). Silage fermentation acids, ethanol and propanol were determined using single-column gas-liquid chromatography (Varian Star 3400 CX GC, equipped with a flame ionisation detector), where samples were injected on column. Ammonia nitrogen concentrations in silage and the silage $\mathrm{pH}$ were determined as described by Steen (1989). The ME concentration of the fresh silages was determined using near-infrared reflectance spectroscopy (NIRS), using a calibration developed for GSs, according to Park et al. (1998).

\section{Statistical analysis}

Differences in the mean chemical composition of the GS and RCGS within each of the harvests $\mathrm{H} 1-\mathrm{H} 3$ were tested for significance by Student's two-tailed $t$-test using Microsoft Excel (2013). In vitro protein degradation mean values were tested for significance by two-way analysis of variance (ANOVA), with "runs" considered as replicates. Mean data for DMI, milk yield, milk composition, LW and BCS, as recorded during the period when each batch of silage was offered and over the entire experimental period, were analysed using ANOVA. When significant, appropriate pre-experimental variables were included as covariates in the model when analysing the corresponding dependant variables (pre-experimental milk yield for milk yield, pre-experimental milk composition values for milk fat, protein, fat-plus-protein and mean daily milk yields; pre-experimental LW for mean LW; pre-experimental BCS for mean and final BCS; pre-experimental LW for forage, concentrate and total DMI). The effects of forage type on the total diet digestibility coefficients, as well as on the $\mathrm{N}$ and GE parameters, were examined using a two-way ANOVA. Mean values for protein degradation were analysed using one-way ANOVA. All data were analysed using GenStat (16th edition; VSN International Ltd, Hemel Hempstead, UK).

\section{Results}

\section{Chemical composition and in vitro protein degradability of silages}

The concentrate offered had the following values: DM, 894 (s.d., 3.1) g/kg; CP, 217 (s.d., 2.54) g/kg DM; ADF, 159 (s.d., 6.7) g/kg DM; NDF, 325 (s.d., 4.0) g/kg DM; ash, 76 (s.d., 1.5) g/kg DM; GE, 18.0 (s.d., 0.04) MJ/kg DM; and starch, 229 (s.d., 8.7) $\mathrm{g} / \mathrm{kg}$ DM. The volatile-corrected ODM content of RCGS was higher than that of GS at $\mathrm{H} 1(P=0.014)$, while the reverse was true at $\mathrm{H} 3(P=0.005)($ Table 1$)$. At $\mathrm{H} 1$, forage $\mathrm{CP}$ (Table 1) tended to be higher in GS than in RCGS $(P=0.074)$, while at $\mathrm{H} 3$, it was lower in GS than in RCGS $(P=0.006)$. At $\mathrm{H} 1$, both the ADF and NDF of GS were higher than in RCGS $(P=0.001, P=0.002$, respectively). At $\mathrm{H} 2$, the $\mathrm{GS}$ had a higher NDF content than RCGS $(P=0.002)$, while the reverse tended to be the case for ADF content $(P=0.059)$. Contents of acetic acid, propionic acid and n-butyric acid were higher in GS than in RCGS at $\mathrm{H} 1$ ( $P=0.005,0.017$ and 0.001 , respectively) and lower in GS than in RCGS at H3 $(P<0.001,<0.005$ and $<0.043$, respectively). Acetic acid content was higher in RCGS than in $\mathrm{GS}$ at $\mathrm{H} 2(P=0.034)$. The RCGS samples tended to have a lower lactic acid content than GS samples at $\mathrm{H} 1$ $(P=0.087)$, while at $\mathrm{H} 3$, it was higher in RCGS than in GS 
Table 1: Chemical composition of grass silage (GS) and red clover-grass silage (RCGS) offered during the 13-wk experimental period at primary growth $(\mathrm{H} 1)$ or the first $(\mathrm{H} 2)$ or second $(\mathrm{H} 3)$ regrowth

\begin{tabular}{|c|c|c|c|c|c|c|c|c|c|c|c|c|}
\hline & \multicolumn{4}{|c|}{ H1 } & \multicolumn{4}{|c|}{$\mathrm{H} 2$} & \multicolumn{4}{|c|}{ H3 } \\
\hline & GS & RCGS & s.e. & $P$-value & GS & RCGS & s.e. & $P$-value & GS & RCGS & s.e. & $P$-value \\
\hline VCODM (g/kg) & 218 & 299 & 18.3 & 0.014 & 188 & 204 & 5.8 & & 283 & 216 & 16.0 & 0.005 \\
\hline Crude protein (g/kg DM) & 132 & 98 & 11.5 & & 137 & 148 & 6.03 & & 158 & 216 & 13.8 & 0.006 \\
\hline Ash (g/kg DM) & 82 & 75 & 2.7 & & 90 & 109 & 2.9 & 0.001 & 87 & 105 & 5.2 & 0.002 \\
\hline ADF (g/kg DM) & 371 & 344 & 3.8 & $<0.001$ & 362 & 383 & 5.6 & 0.023 & 262 & 269 & 6.1 & \\
\hline NDF (g/kg DM) & 631 & 596 & 5.7 & 0.002 & 625 & 565 & 13.2 & 0.010 & 482 & 462 & 9.9 & \\
\hline $\mathrm{pH}$ & 4.3 & 4.2 & 0.09 & & 4.4 & 4.7 & 0.07 & 0.014 & 4.5 & 4.7 & 0.06 & \\
\hline Lactic acid (g/kg DM) & 97.1 & 67.3 & 14.13 & & 83.0 & 31.1 & 13.5 & 0.029 & 80.5 & 96.9 & 11.50 & \\
\hline Acetic acid (g/kg DM) & 22.6 & 12.5 & 1.85 & 0.005 & 24.2 & 38.7 & 1.99 & 0.001 & 25.9 & 36.3 & 3.36 & $<0.001$ \\
\hline Propionic acid (g/kg DM) & 2.4 & 0.7 & 0.39 & 0.017 & 1.9 & 3.8 & 0.51 & 0.036 & 0.5 & 3.7 & 0.78 & 0.005 \\
\hline n-Butyric acid (g/kg DM) & 14.1 & 3.6 & 1.33 & 0.001 & 15.3 & 21.6 & 3.24 & & 0.0 & 3.6 & 0.98 & 0.043 \\
\hline Propanol (g/kg DM) & 0.4 & 0.0 & 0.20 & & 0.0 & 0.0 & 0.00 & & 0.0 & 0.1 & 0.07 & \\
\hline Ethanol (g/kg DM) & 1.3 & 0.3 & 2.04 & & 9.9 & 2.1 & 1.21 & 0.006 & 7.7 & 6.6 & 2.51 & \\
\hline Ammonia (g/kg total $\mathrm{N})$ & 17.4 & 9.2 & 1.25 & 0.002 & 18.7 & 17.0 & 0.89 & & 10.3 & 14.3 & 1.04 & 0.027 \\
\hline $\begin{array}{l}\text { Metabolisable energy } \\
\text { (MJ/kg DM) }\end{array}$ & 10.4 & 10.5 & 0.14 & & 10.2 & 9.8 & 0.20 & & 10.5 & 9.8 & 0.19 & \\
\hline
\end{tabular}

VCODM = volatile-corrected oven dry matter; $A D F=$ acid detergent fibre; NDF = neutral detergent fibre.

$(P=0.044)$. Ammonia nitrogen was higher, respectively, in GS than in RCGS at $\mathrm{H} 1(P=0.002)$, and $\mathrm{pH}$ was lower in GS than in RCGS at H2 $(P=0.014)$. The ME contents of the two silages were not significantly different at either $\mathrm{H} 1$ or $\mathrm{H} 2$, while tending ( $P=0.088)$ to be higher for the $\mathrm{GS}$ at $\mathrm{H} 3$.

Across the six forages offered, there were no differences in $\mathrm{D}$ (potentially degradable fraction) or $K_{\mathrm{d}}$ (degradation rate) (Table 2). The potentially soluble fraction (S) was significantly higher in GS than in RCGS at H3 only. The undegradable fraction $(U)$ was significantly higher in RCGS than in GS at each of $\mathrm{H} 2$ and $\mathrm{H} 3$. The RCGS had a significantly higher RUCP at $\mathrm{H} 2$ and $\mathrm{H} 3$, while the reverse was true for effectively degraded $C P(E D C P)$. While in vitro intestinal digestibility of $\mathrm{CP}$ (IVCPD) was higher with RCGS at $\mathrm{H} 1$, it was unaffected by silage type at either $\mathrm{H} 2$ or $\mathrm{H} 3$. The in vitro intestinal digestibility of the undegradable CP in the rumen (IVCPDCP) was higher with RCGS at $\mathrm{H} 3$ but did not differ at either $\mathrm{H} 1$ or $\mathrm{H} 2$ (Table 2).

Table 2: In vitro ruminal protein degradation kinetics of grass silage (GS) or red clover-grass silage (RCGS) produced from the primary growth $(\mathrm{H} 1)$, the first regrowth $(\mathrm{H} 2)$, or the second regrowth $(\mathrm{H} 3)$

\begin{tabular}{|c|c|c|c|c|c|c|c|c|}
\hline & GS H1 & RCGS H1 & GS H2 & RCGS H2 & GS H3 & RCGS H3 & s.e. & $P$-value \\
\hline $\mathrm{S}(\% \mathrm{CP})$ & $53.4^{a}$ & $55.9^{\mathrm{a}}$ & $34.3^{\mathrm{b}}$ & $27.3^{b}$ & $63.6^{\mathrm{a}}$ & $32.0^{\mathrm{b}}$ & 4.76 & 0.017 \\
\hline $\mathrm{D}(\% \mathrm{CP})$ & 26.4 & 27.9 & 35.1 & 35.4 & 28.6 & 34.2 & 3.99 & \\
\hline $\mathrm{U}(\% \mathrm{CP})$ & $20.2^{\mathrm{c}}$ & $16.1^{\mathrm{c}}$ & $30.6^{b}$ & $37.3^{\mathrm{a}}$ & $7.8^{\mathrm{d}}$ & $33.8^{a, b}$ & 1.64 & $<0.001$ \\
\hline $\mathrm{K}_{\mathrm{d}}(\% \mathrm{~h})$ & 15.0 & 11.2 & 20.6 & 9.1 & 8.2 & 10.9 & 6.20 & \\
\hline RUCP (\%CP) & $29.3^{c}$ & $25.8^{\mathrm{c}, \mathrm{d}}$ & $41.7^{b}$ & $51.4^{a}$ & $19.8^{\mathrm{d}}$ & $46.4^{\mathrm{a}, \mathrm{b}}$ & 2.30 & 0.001 \\
\hline EDCP (\%CP) & $70.7^{\mathrm{b}}$ & $74.2^{\mathrm{a}, \mathrm{b}}$ & $58.3^{c}$ & $48.6^{d}$ & $80.2^{\mathrm{a}}$ & $53.6^{c, d}$ & 2.30 & 0.001 \\
\hline IVCPD (\%) & $71.1^{\mathrm{b}}$ & $84.2^{\mathrm{a}}$ & $65.7^{\circ}$ & $62.9^{c, d}$ & $55.6^{e}$ & $58.9^{\mathrm{d}, \mathrm{e}}$ & 1.35 & $<0.001$ \\
\hline IVCPDCP (\%) & $20.9^{b}$ & $21.7^{\mathrm{b}}$ & $27.5^{\mathrm{a}, \mathrm{b}}$ & $32.4^{\mathrm{a}}$ & $11.0^{\circ}$ & $27.6^{\mathrm{a}, \mathrm{b}}$ & 2.14 & 0.009 \\
\hline
\end{tabular}

Mean values with different letters ${ }^{a-e}$ within the same row differ significantly.

$\mathrm{CP}=$ crude protein; $\mathrm{S}=$ potential soluble fraction in the in vitro ruminal incubation; $\mathrm{D}=$ potentially degradable fraction in the in vitro

ruminal incubation; $U=$ undegradable fraction; $K_{d}=$ degradation rate; $R U C P=$ rumen undegraded $C P$; EDCP = effectively degraded $C P$;

IVCPD = in vitro intestinal digestibility of CP; IVCPDCP = in vitro intestinal digestibility of the undegradable CP in the rumen. 
Table 3: Performance of dairy cows offered either grass silage (GS) or red clover-grass silage (RCGS) from primary growth $(\mathrm{H} 1)$, first regrowth $(\mathrm{H} 2)$ or second regrowth $(\mathrm{H} 3)$

\begin{tabular}{|c|c|c|c|c|}
\hline & \multicolumn{2}{|c|}{ Treatment } & \multirow[b]{2}{*}{ s.e. } & \multirow[b]{2}{*}{$P$-value } \\
\hline & GS & RCGS & & \\
\hline \multicolumn{5}{|l|}{ H1 } \\
\hline Silage DMI (kg/d) & 8.8 & 11.7 & 0.28 & $<0.001$ \\
\hline Total DMI (kg/d) & 15.9 & 18.8 & 0.28 & $<0.001$ \\
\hline Milk yield (kg/d) & 24.9 & 25.5 & 0.36 & \\
\hline Milk fat $(\mathrm{g} / \mathrm{kg})$ & 47.3 & 47.3 & 1.10 & \\
\hline Milk protein (g/kg) & 31.6 & 32.3 & 0.41 & \\
\hline Milk lactose (g/kg) & 46.5 & 46.9 & 0.33 & \\
\hline Fat + protein yield $(\mathrm{kg} / \mathrm{d})$ & 2.69 & 2.72 & 0.094 & \\
\hline Average live weight (kg) & 549 & 558 & 2.9 & 0.049 \\
\hline Average body condition score & 2.56 & 2.68 & 0.037 & 0.042 \\
\hline \multicolumn{5}{|l|}{ H2 } \\
\hline Silage DMI (kg/d) & 9.2 & 10.4 & 0.28 & 0.006 \\
\hline Total DMI (kg/d) & 16.4 & 17.5 & 0.28 & 0.006 \\
\hline Milk yield (kg/d) & 22.1 & 23.1 & 0.44 & \\
\hline Milk fat $(\mathrm{g} / \mathrm{kg})$ & 45.3 & 45.2 & 0.98 & \\
\hline Milk protein (g/kg) & 32.0 & 30.8 & 0.47 & \\
\hline Milk lactose (g/kg) & 45.4 & 45.4 & 0.47 & \\
\hline Fat + protein yield $(\mathrm{kg} / \mathrm{d})$ & 2.47 & 2.43 & 0.090 & \\
\hline Average live weight (kg) & 547 & 550 & 4.3 & \\
\hline Average body condition score & 2.52 & 2.62 & 0.051 & \\
\hline \multicolumn{5}{|l|}{ H3 } \\
\hline Silage DMI (kg/d) & 12.3 & 11.5 & 0.45 & \\
\hline Total DMI (kg/d) & 19.5 & 18.7 & 0.45 & \\
\hline Milk yield (kg/d) & 21.8 & 24.7 & 0.58 & 0.002 \\
\hline Milk fat $(\mathrm{g} / \mathrm{kg})$ & 47.8 & 43.1 & 0.82 & $<0.001$ \\
\hline Milk protein (g/kg) & 35.1 & 31.4 & 0.45 & $<0.001$ \\
\hline Milk lactose (g/kg) & 44.5 & 45.2 & 0.55 & \\
\hline Fat + protein yield $(\mathrm{kg} / \mathrm{d})$ & 2.74 & 2.41 & 0.085 & \\
\hline Average live weight (kg) & 569 & 559 & 5.8 & \\
\hline Average body condition score & 2.53 & 2.58 & 0.051 & \\
\hline \multicolumn{5}{|l|}{ H1-3 } \\
\hline Silage DMI (kg/d) & 9.5 & 11.1 & 0.26 & $<0.001$ \\
\hline Total DMI (kg/d) & 16.7 & 18.3 & 0.26 & $<0.001$ \\
\hline Milk yield (kg/d) & 23.4 & 24.4 & 0.39 & \\
\hline Milk fat $(\mathrm{g} / \mathrm{kg})$ & 46.8 & 45.8 & 0.82 & \\
\hline Milk protein $(\mathrm{g} / \mathrm{kg})$ & 32.3 & 31.5 & 0.41 & \\
\hline Milk lactose (g/kg) & 45.7 & 46.0 & 0.40 & \\
\hline Fat + protein yield $(\mathrm{kg} / \mathrm{d})$ & 2.62 & 2.56 & 0.080 & \\
\hline
\end{tabular}

Table 3: (continued)

\begin{tabular}{lcccc}
\hline \multicolumn{5}{c}{ Treatment } \\
& GS & RCGS & s.e. & $P$-value \\
\hline Average live weight $(\mathrm{kg})$ & 552 & 555 & 3.71 & \\
Average body condition score & 2.54 & 2.64 & 4.21 & \\
End of study live weight $(\mathrm{kg})$ & 569 & 559 & 5.8 & \\
End of study body condition score & 2.52 & 2.56 & 0.050 & \\
\hline
\end{tabular}

$\mathrm{DMI}=\mathrm{DM}$ intake

\section{Cow performance}

Silage DMI was lower in GS than in RCGS treatments in $\mathrm{H} 1(P<0.001)$ and $\mathrm{H} 2(P=0.006)$ and across the entire experimental period ( $\mathrm{H} 1-\mathrm{H} 3: P<0.001$; Table 3$)$. Differences in total DMI were similar. Milk yield was unaffected by silage type at $\mathrm{H} 1(P>0.05)$, tended to be lower for cows offered GS than RCGS at H2 $(P=0.093)$, while being significantly lower for those offered $\mathrm{GS}$ at $\mathrm{H} 3(P=0.002)$. Milk fat concentration was unaffected by treatment at $\mathrm{H} 1$ and $\mathrm{H} 2$, but it was higher in GS than in RGCS at H3 $(P<0.001)$. Similarly, milk protein concentration was unaffected by treatment at $\mathrm{H} 1$, tended to be significantly lower for cows offered RCGS than GS at $\mathrm{H} 2(P=0.080)$ and was lower for cows offered RCGS than GS at H3 $(P<0.001)$. Milk fat + protein yield was unaffected by treatment at either $\mathrm{H} 1$ or $\mathrm{H} 2$, but it was lower with cows offered RCGS than GS at H3 $(P=0.001)$. Cows offered RCGS were heavier $(P=0.049)$ and had a higher $\operatorname{BCS}(P=0.042)$ than those offered GS at $\mathrm{H} 1$, while neither LW nor BCS was affected by treatment at either $\mathrm{H} 2$ or $\mathrm{H} 3$.

\section{Nutrient utilisation}

None of the digestibility parameters examined differed between GS and RCGS at H1 $(P>0.05)$ (Table 4). Dry matter digestibility, organic matter digestibility and digestible organic matter in DM were higher for GS than for RCGS at $\mathrm{H} 2(P<0.001, P=0.003$ and $P<0.001$, respectively) and $\mathrm{H} 3$ $(P=0.006,0.007$ and 0.002 , respectively). Digestibility of ADF and NDF was higher for GS than for RCGS at $\mathrm{H} 2(P<0.001$ and $P=0.017$, respectively) and $\mathrm{H} 3(P=0.009$ and 0.037 , respectively).

Faecal N/N intake was higher for RCGS than for GS at $\mathrm{H} 1$ $(P=0.019)$ but did not differ between silages at $\mathrm{H} 2$ and $\mathrm{H} 3$, while urinary $\mathrm{N} / \mathrm{N}$ intake was higher for GS than for RCGS at $\mathrm{H} 1(P=0.008$; Table 5). Manure $\mathrm{N} / \mathrm{N}$ intake was higher for GS at $\mathrm{H} 1(P=0.005)$, while the reverse was observed at $\mathrm{H} 2(P=0.002)$. Milk $\mathrm{N} / \mathrm{N}$ intake was higher for $\mathrm{GS}$ than for RCGS at $\mathrm{H} 2$ and $\mathrm{H} 3(P=0.007$ and 0.020 , respectively). Retained N/N intake was higher for GS than for RCGS at $\mathrm{H} 2$ $(P=0.035)$, but it was unaffected at $\mathrm{H} 1$ and $\mathrm{H} 3$. At $\mathrm{H} 1$, faecal 
Table 4: Digestibility of components of DM consumed by dairy cows offered either grass silage (GS) or red clover-grass silage (RCGS) produced from primary growth $(\mathrm{H} 1)$, first regrowth $(\mathrm{H} 2)$ or second regrowth $(\mathrm{H} 3)$

\begin{tabular}{|c|c|c|c|c|}
\hline \multicolumn{5}{|c|}{ Treatment } \\
\hline & GS & RCGS & s.e. & $P$-value \\
\hline \multicolumn{5}{|l|}{ H1 } \\
\hline \multicolumn{5}{|l|}{ Digestibility (kg/kg) } \\
\hline DM & 0.74 & 0.75 & 0.006 & \\
\hline Organic matter & 0.75 & 0.76 & 0.006 & \\
\hline $\begin{array}{l}\text { Digestible organic } \\
\text { matter in DM }\end{array}$ & 0.69 & 0.70 & 0.005 & \\
\hline ADF & 0.71 & 0.71 & 0.006 & \\
\hline NDF & 0.69 & 0.70 & 0.007 & \\
\hline \multicolumn{5}{|l|}{ H2 } \\
\hline \multicolumn{5}{|l|}{ Digestibility (kg/kg) } \\
\hline DM & 0.74 & 0.68 & 0.006 & 0.001 \\
\hline Organic matter & 0.75 & 0.70 & 0.008 & 0.003 \\
\hline $\begin{array}{l}\text { Digestible organic } \\
\text { matter in DM }\end{array}$ & 0.69 & 0.63 & 0.007 & 0.001 \\
\hline ADF & 0.75 & 0.63 & 0.010 & 0.001 \\
\hline NDF & 0.69 & 0.55 & 0.031 & 0.017 \\
\hline \multicolumn{5}{|l|}{ H3 } \\
\hline \multicolumn{5}{|l|}{ Digestibility (kg/kg) } \\
\hline DM & 0.76 & 0.71 & 0.009 & 0.006 \\
\hline Organic matter & 0.77 & 0.73 & 0.007 & 0.007 \\
\hline $\begin{array}{l}\text { Digestible organic } \\
\text { matter in DM }\end{array}$ & 0.70 & 0.65 & 0.007 & 0.002 \\
\hline ADF & 0.78 & 0.72 & 0.010 & 0.009 \\
\hline NDF & 0.71 & 0.66 & 0.012 & 0.037 \\
\hline
\end{tabular}

$\mathrm{ADF}=$ acid detergent fibre; NDF = neutral detergent fibre.

$\mathrm{N} /$ manure $\mathrm{N}$ was higher in RCGS than in $\mathrm{GS}(P=0.010)$, while urinary $\mathrm{N} /$ manure $\mathrm{N}$ was higher for GS than for RCGS $(P=0.010)$.

Gross energy digestibility and digestible energy (DE)/GE were higher with GS than with RCGS at $\mathrm{H} 2(P=0.003$ and 0.002 , respectively) but not at $\mathrm{H} 1$ and $\mathrm{H} 3$ (Table 6). Milk energy/ ME intake tended to be higher with GS than with RCGS at $\mathrm{H} 1(P=0.094)$ while being higher at $\mathrm{H} 3(P<0.001)$. At $\mathrm{H} 2$, the proportion of digestible energy intake (DEI) that was lost as faecal and urinary energy was higher in RCGS than in GS $(P=0.002$ and 0.003 , respectively), while at $\mathrm{H} 3$, faecal energy/DEI was unaffected by treatment, while urine energy/ DEI was higher with $\mathrm{GS}(P=0.032)$.
Table 5: Nitrogen utilisation of dairy cows offered either grass silage (GS) or red clover-grass silage (RCGS) produced from primary growth $(\mathrm{H} 1)$, first regrowth $(\mathrm{H} 2)$ or second regrowth $(\mathrm{H} 3)$

\begin{tabular}{|c|c|c|c|c|}
\hline \multicolumn{5}{|c|}{ Treatment } \\
\hline & GS & RCGS & s.e. & $P$-value \\
\hline \multicolumn{5}{|l|}{ H1 } \\
\hline \multicolumn{5}{|l|}{ N utilisation $(g / g)$} \\
\hline Faecal $N / N$ intake & 0.31 & 0.37 & 0.014 & 0.019 \\
\hline Urinary $\mathrm{N} / \mathrm{N}$ intake & 0.33 & 0.22 & 0.019 & 0.008 \\
\hline Manure N/N intake & 0.63 & 0.59 & 0.007 & 0.005 \\
\hline Milk N/N intake & 0.28 & 0.29 & 0.016 & \\
\hline Retained N/N intake & 0.09 & 0.12 & 0.017 & \\
\hline Faecal $\mathrm{N} /$ manure $\mathrm{N}$ & 0.48 & 0.62 & 0.027 & 0.010 \\
\hline Urinary $\mathrm{N} /$ manure $\mathrm{N}$ & 0.52 & 0.38 & 0.027 & 0.010 \\
\hline \multicolumn{5}{|l|}{ H2 } \\
\hline \multicolumn{5}{|l|}{$N$ utilisation $(g / g)$} \\
\hline Faecal N/N intake & 0.29 & 0.32 & 0.010 & \\
\hline Urinary $\mathrm{N} / \mathrm{N}$ intake & 0.26 & 0.33 & 0.019 & \\
\hline Manure N/N intake & 0.56 & 0.65 & 0.012 & 0.002 \\
\hline Milk N/N intake & 0.26 & 0.23 & 0.005 & 0.007 \\
\hline Retained N/N intake & 0.19 & 0.13 & 0.015 & 0.035 \\
\hline Faecal $\mathrm{N} /$ manure $\mathrm{N}$ & 0.53 & 0.50 & 0.023 & \\
\hline Urinary $\mathrm{N} /$ manure $\mathrm{N}$ & 0.47 & 0.50 & 0.023 & \\
\hline \multicolumn{5}{|l|}{ H3 } \\
\hline \multicolumn{5}{|l|}{$N$ utilisation $(g / g)$} \\
\hline Faecal $\mathrm{N} / \mathrm{N}$ intake & 0.42 & 0.41 & 0.013 & \\
\hline Urinary $\mathrm{N} / \mathrm{N}$ intake & 0.44 & 0.47 & 0.021 & \\
\hline Manure N/N intake & 0.86 & 0.87 & 0.023 & \\
\hline Milk N/N intake & 0.28 & 0.24 & 0.009 & 0.020 \\
\hline Retained N/N intake & -0.14 & -0.11 & 0.018 & \\
\hline Faecal $\mathrm{N} /$ manure $\mathrm{N}$ & 0.50 & 0.46 & 0.021 & \\
\hline Urinary $\mathrm{N} /$ manure $\mathrm{N}$ & 0.50 & 0.54 & 0.021 & \\
\hline
\end{tabular}

\section{Discussion}

This study examined the performance and nutrient utilisation of dairy cows offered silages produced from three successive harvests of a red clover-perennial ryegrass sward and a perennial ryegrass sward. While previous studies have examined the impact of mixing red clover silages and GS on cow performance post-harvest, few have examined silages produced from mixed swards across multiple harvests, as would be commonly practised under commercial farm conditions. 
Table 6: Gross energy digestibility and energy utilisation of dairy cows offered either grass silage (GS) or red clover-grass silage (RCGS) produced from primary growth $(\mathrm{H} 1)$, first regrowth $(\mathrm{H} 2)$ or second regrowth $(\mathrm{H} 3)$

\begin{tabular}{lcccc}
\hline \multicolumn{5}{c}{ Treatment } \\
& GS & RCGS & s.e. & P-value \\
\hline H1 & & & & \\
GE digestibility & 0.72 & 0.73 & 0.006 & \\
Energy utilisation (MJ/MJ) & & & & \\
$\quad$ DE/GE & 0.73 & 0.73 & 0.006 & \\
Milk energy/ME & 0.40 & 0.34 & 0.021 & \\
Faeces energy/DEI & 0.38 & 0.37 & 0.011 & \\
$\quad$ Urine energy/DEI & 0.03 & 0.03 & 0.003 & \\
H2 & & & & \\
GE digestibility & 0.73 & 0.67 & 0.008 & 0.003 \\
Energy utilisation (MJ/MJ) & & & & \\
DE/GE & 0.73 & 0.67 & 0.008 & 0.002 \\
Milk energy/ME & 0.39 & 0.40 & 0.009 & \\
Faeces energy /DEI & 0.37 & 0.49 & 0.015 & 0.002 \\
$\quad$ Urine energy /DEI & 0.03 & 0.06 & 0.004 & 0.003 \\
H3 & & & & \\
GE digestibility & 0.66 & 0.67 & 0.009 & \\
Energy utilisation (MJ/MJ) & & & & \\
DE/GE & 0.66 & 0.67 & 0.009 & \\
Milk energy/ME & 0.51 & 0.42 & 0.011 & 0.001 \\
Faeces energy /DEI & 0.51 & 0.49 & 0.015 & \\
Urine energy /DEI & 0.09 & 0.07 & 0.004 & 0.032 \\
\hline
\end{tabular}

$\mathrm{DEI}=$ digestible energy intake; $\mathrm{GE}$ = gross energy; $\mathrm{ME}=$ metabolisable energy.

\section{Sward production}

The annual DM production from the RCGS sward (10.0 t DM/ ha) in the current study was similar to that recorded in a fieldscale study by Castle \& Watson (1974) in western Scotland (10.9 t DM/ha). However, these yields were considerably lower than the $14.7 \mathrm{t} \mathrm{DM} /$ ha reported by Roberts et al. (1990) from a mixed red clover-grass sward in its first harvest year in southern Scotland.

While pure red clover crops have been reported to fix up to $250 \mathrm{~kg} \mathrm{~N} / \mathrm{ha}$ (Smith et al., 1985), less is known about the $\mathrm{N}$-fixing potential of red clover within grass swards. In the current study, the total annual DM produced from the mixed sward (which received only $22 \mathrm{~kg} \mathrm{~N}$, in early spring) was only $0.4 \mathrm{t} \mathrm{DM} /$ ha less than that produced from the pure perennial ryegrass sward (10.4 $\mathrm{t} \mathrm{DM} / \mathrm{ha})$, which received a total of $315 \mathrm{~kg} \mathrm{~N} / \mathrm{ha}$. This suggests that the amount of $\mathrm{N}$ the red clover component contributed to the sward was equivalent to a grass sward receiving approximately $263 \mathrm{~kg} \mathrm{~N} / \mathrm{ha}$, assuming that an additional $0.4 \mathrm{t} \mathrm{DM} / \mathrm{ha}$ was produced by $30 \mathrm{~kg} \mathrm{~N} / \mathrm{ha}$ (Morrison et al., 1980), that is $315-30-22 \mathrm{~kg} \mathrm{~N} / \mathrm{ha}$.

\section{Silage characteristics}

Within each harvest, both the grass and the grass-red clover silages were produced under the same climatic conditions, with both swards wilted for similar periods. However, silage DM contents indicate that wilting conditions were poor within the current study, as occurs frequently in Ireland. In general, red clover tends to have higher moisture content than grass at any given time during the growth cycle (Hynes et al., 2018), and this likely accounts for the lower DM of RCGS than GS at $\mathrm{H} 3$, the former estimated to contain approximately $60 \%$ red clover. In contrast, the higher DM content of the RCGS than GS at H1 is likely to reflect the lower total yield of crop, resulting in more rapid drying than the heavier GS crop (Wright et al., 1997) and the low red clover proportion with this crop at first harvest (visually estimated to be approximately $20 \%$ ). The CP content of a pure red clover sward has been found to increase progressively with harvest. For example, in a trial in Ireland, CP increased from $155 \mathrm{~g} / \mathrm{kg}$ at the first to $263 \mathrm{~g} / \mathrm{kg}$ at the fourth harvest (Clavin et al., 2017). The increase in the CP content of the RCGS silages $(98,148$ and $216 \mathrm{~g} / \mathrm{kg}$ DM for $\mathrm{H} 1$, $\mathrm{H} 2$ and $\mathrm{H} 3$, respectively) reflects the increasing CP content of the swards as red clover content increased with progress through the growing season, in addition to the seasonal increase in CP content as found by Clavin et al. (2017). This compares to a CP content of the GS at H3 of $158 \mathrm{~g} / \mathrm{kg} \mathrm{DM}$, despite the much higher rate of $\mathrm{N}$ fertiliser applied to $\mathrm{GS}$ than to RCGS.

The presence of vegetative red clover in the sward is likely to have contributed to the lower concentrations of ADF and NDF in RCGS than in GS at $\mathrm{H} 1$. The vegetative state of both sward types at $\mathrm{H} 3$ would have been responsible for the lower ADF and NDF contents at this harvest compared to $\mathrm{H} 1$ and $\mathrm{H} 2$. The higher $\mathrm{pH}$ for red clover silage than $\mathrm{GS}$ at $\mathrm{H} 2$ is similar to the 0.7-unit difference between the two silage types observed by Moorby et al. (2009). While this can be attributed to the high buffering capacity of red clover compared to perennial ryegrass (King et al., 2012), the reason that no such effect was observed at $\mathrm{H} 3$ is unclear. While red clover silages tend to have higher concentrations of volatile fatty acids (VFAs) than GS (Moorby et al., 2009), no consistent trends in VFA content between RCGS and GS were observed in the current study, possibly due to the lower DM content of RCGS than GS within harvests.

Although levels are variable, red clover PPO can oxidise phenols to produce quinones that bind with specific sites on some proteins, reducing proteolysis in the rumen (Theodorou et al., 2006). The presence of PPO may explain the higher proportion of CP that was undegraded in the rumen in RCGS 
compared to $\mathrm{GS}$ at $\mathrm{H} 2$ and $\mathrm{H} 3$ when assessed by the in vitro method. The digestibility of undegradable protein declined with successive harvests, thus suggesting less $\mathrm{N}$ to be readily available for intestinal absorption. Johansen et al. (2017) found total tract digestibility of CP in a perennial ryegrassred clover silage to be slightly but significantly lower than that of the corresponding GS, but the rumen degradation rate of $\mathrm{CP}$ in red clover was faster than in perennial ryegrass. In our study, although total degradation of protein in RGCS was lower than in GS, there was no difference in degradation rate between the two silages.

\section{Intake and performance}

Over the entire experimental period, forage DMIs with RCGS were $1.6 \mathrm{~kg} / \mathrm{d}$ higher than for GS. However, this effect was not consistent across harvests, with intakes with RCGS being higher at $\mathrm{H} 1$ and $\mathrm{H} 2$ but not at $\mathrm{H} 3$. In general, intakes increase with red clover inclusion in the diet. For example, Moorby et al. (2009), with a diet containing a mixture of red clover and GS (one third red clover on a DM basis) and Kuoppala et al. (2009), with a diet containing equal mixtures of red clover and GS on a DM basis, found intakes to be 1.1 and $2.0 \mathrm{~kg} \mathrm{DM} / \mathrm{d}$ higher, respectively, than with pure GS. Halmemies-Beauchet-Filleau et al. (2012) also found an increase in forage DMI when red clover silage was mixed with GS, compared to a GS-only diet. While in vivo digestibility and in vitro degradability characteristics of the two silage types did not differ for any parameter at H1, RCGS had a much higher DM content at $\mathrm{H} 1$ than at subsequent harvests, potentially contributing to the higher DMI at this harvest. In addition, RCGS had a lower fibre content than GS, reflecting the visibly less mature state of the crop at harvest than at later harvests. However, the higher intakes with RCGS than with GS at $\mathrm{H} 2$ occurred despite the two silages having similar degradability characteristics and DM content and the RCGS having a lower digestibility coefficient for each of the parameters measured. Nevertheless, the NDF content of the RCGS was substantially lower than for the GS. In contrast, at H3, although red clover content was at its highest, DMI of RCGS was similar to that of GS at this harvest. As with $\mathrm{H} 2$, digestibility of RCGS was lower than that of GS; however, the similar NDF contents between the two silages may have been a contributing factor (Weisbjerg \& Soegaard, 2008), combined with the higher DM content of the GS. A similar effect was observed by Halmemies-BeauchetFilleau et al. (2014).

Dry matter intake is partially inversely related to the concentration of NDF and directly related to the rate of particle breakdown of feed and rumen digesta outflow (Kuoppala et al., 2009). Rate of fermentation in the rumen and subsequent particle breakdown are considered to contribute to the rate of rumen clearance (Moseley \& Jones, 1984), which in turn influences DMI in legumes (Dewhurst, 2013). Legume leaves are more easily broken down into smaller particles than grass leaves (Mtengeti et al., 1996), and, as a consequence, rumen fermentation is generally increased when red clover silage is offered (Vanhatalo et al., 2009). However, this increase is not always associated with an increase in production of VFAs (Dewhurst et al., 2003b).

In general, evidence within the literature suggests that red clover inclusion in the diet increases milk yields (Moorby et al., 2009; Dewhurst, 2013), with this normally attributed to higher DMIs. In agreement with these findings, over the entire experimental period, milk yield tended to be higher with RCGS. However, this overall effect masks a number of underlying trends and effects within individual harvests. For example, there was a trend for the milk yield advantage to increase with increasing red clover content in the silages $(P=0.228,0.093$ and 0.002 for $\mathrm{H} 1, \mathrm{H} 2$ and $\mathrm{H} 3$, respectively), with a difference of $2.9 \mathrm{~kg} / \mathrm{d}$ in favour of RCGS at H3. The absence of a milk yield benefit with RCGS at $\mathrm{H} 1$, despite the significantly higher intakes, may have been due to the low overall CP content in the diet (143 g/kg DM with RCGS, compared to $169 \mathrm{~g} / \mathrm{kg}$ DM with GS), a reflection of the low application of $\mathrm{N}$ fertiliser and the low red clover content. The additional energy deposited as body tissue with this treatment supports the RCGS diet having a low protein content. Despite similar intakes at H3, RCGS produced a significantly higher milk yield than GS. However, fat + protein yield was lower for RCGS than for GS.

Offering RCGS had no effect on milk fat content at $\mathrm{H} 1$ and $\mathrm{H} 2$, while reducing milk fat content at $\mathrm{H} 3$. The poor milk fat response to red clover inclusion is in general agreement with the findings of a number of other studies (Dewhurst et al., 2003a; Moorby et al., 2009; Vanhatalo et al., 2009; Johansen et al., 2017). Milk fat production is associated with the availability of acetic and butyric acid in the rumen, which requires degraded fibre to undergo bio-hydrogenation (Murphy et al., 2000). Low ADF and NDF digestibility leads to a reduction in betahydroxybutyrate available for de novo fat synthesis within the mammary gland (Heinriches et al., 1997). Furthermore, PPO lowers rumen bio-hydrogenation of polyunsaturated fatty acids (PUFA), with PUFA known to inhibit milk fat synthesis in the mammary gland. Further, lipids may also be incorporated physically in protein complexes resulting from the action of PPO (Halmemies-Beauchet-Filleau et al., 2012). Digestibility of NDF and ADF was lower with RCGS than with GS at H2 and $\mathrm{H} 3$. At $\mathrm{H} 2$, intake was higher in RCGS than in GS and, so, despite the lower digestibility of NDF and ADF, intake of digestible fibre in the two treatments would have been similar. In contrast, there being no significant difference in intake between the two silages at $\mathrm{H} 3$, the lower digestibility of NDF and ADF with RCGS would explain the lower fat content of the milk in that treatment.

In a meta-analysis of 43 studies comparing grass and legume silages offered to dairy cows, in which 29 involved 
red clover-grass comparisons, milk protein from perennial ryegrass- and red clover-based diets was $31.9 \mathrm{~g} / \mathrm{kg}$ and $31.5 \mathrm{~g} / \mathrm{kg}$, respectively (Johansen et al., 2018). Similarly, in a review that included eight studies comparing red clover and perennial ryegrass silages, with the exception of one study that showed a slight increase in milk protein content due to red clover silage, milk protein was either unaffected or was higher with GS than with red clover silage (Dewhurst et al., 2003a). The results of the current study are in agreement with those from other studies, with milk protein unaffected at $\mathrm{H}$, tending to be higher with the $\mathrm{GS}$ at $\mathrm{H} 2$ and being significantly higher at $\mathrm{H} 3$. The effects in the latter harvests may have been due to PPO in red clover catalysing the synthesis of quinones, which complex with, and thereby inactivate, enzymes such as proteases, hence reducing protein availability (Lee, 2014).

\section{Nitrogen and energy utilisation}

Effects of diet on $\mathrm{N}$ and energy utilisation parameters were inconsistent across harvests. For example, a higher proportion of $\mathrm{N}$ intake was excreted as faecal $\mathrm{N}$ and a lower proportion as urinary $\mathrm{N}$ with the RCGS treatment at $\mathrm{H} 1$. However, at $\mathrm{H} 2$, there was a trend for urinary N/N intake to be higher with RCGS, while manure N/N intake was higher. No differences were observed at H3. These effects largely reflect the relationships between milk protein yield and DMI, as well as the increasing CP content of the RCGS diet moving from $\mathrm{H} 1$ to $\mathrm{H} 3$ (Cheng et al., 2011). For example, as the red clover content in the silages increased at $\mathrm{H} 2$ and $\mathrm{H} 3$, proportionately less $\mathrm{N}$ was partitioned to milk in RCGS than in GS. Moreover, findings by Moorby et al. (2009) with treatments involving 3:1 and 3:2 ratios of GS: red clover silage versus GS illustrated that although no differences were found in the overall $\mathrm{N}$ balance, apparent partitioning of dietary $\mathrm{N}$ into milk was significantly lower in diets with $100 \%$ red clover.

There was no clear relationship between rumen degradation (or intestinal digestion) of protein and $\mathrm{N}$ utilisation efficiency. For example, a higher content of digestible intestinal protein in RCGS than in GS was associated with a higher proportion of $\mathrm{N}$ partitioned to faeces at $\mathrm{H} 1$. A higher proportion of ruminal undegraded protein was associated with a lower proportion of partitioned to milk in the same treatment at H3. Faeces have less of an environmental impact than urine as they mineralise more slowly (Haynes \& Williams, 1993). Urinary $\mathrm{N}$ is rapidly converted to $\mathrm{NH}_{3}$ shortly after it is excreted (Varel et al., 1999) and then to volatile nitrous oxides, which are potent greenhouse gases (Kebreab et al., 2004). In contrast, faecal $\mathrm{N}$ is converted to $\mathrm{NH}_{3}$ at a much slower rate and is retained in the soil, contributing to accumulation of soil organic matter (Waghorn, 2008).

While Vanhatalo et al. (2009) found a positive effect on wholebody $\mathrm{N}$ balance by partially replacing GS with red clover silage, no such effect was observed in the current study at
$\mathrm{H} 1$ and H3, in agreement with Bertilsson \& Murphy (2003), while the opposite effect was observed at $\mathrm{H} 2$. However, as only four animals per treatment were used in the nutrient utilisation studies at each harvest, this was not ideal for identifying differences in $\mathrm{N}$ retention. Even with activated PPO (found in fresh samples vs. ensiled), Moorby et al. (2009) found that when feeding fresh red clover with a CP content of approximately $20 \%, \mathrm{~N}$ utilisation by dairy cows was not improved relative to the inactivated PPO. They considered that a CP of $20 \%$, similar to that at $\mathrm{H} 3$ in RCGS, was too high for PPO to complex with proteases to have an impact, resulting in less $\mathrm{N}$ available for milk protein synthesis but increasing the likelihood of the creation of an environmental burden (Castillo et al., 2000).

Differences in energy utilisation between treatments again largely reflect differences in fat + protein yields, relative to nutrient intake. In addition, ammonia - which results from the additional dietary protein degraded in the rumen - is detoxified in the liver, requiring energy (Canfield et al., 1990), and this may have contributed to the lower milk energy/ME intake with the clover-rich RCGS diets at $\mathrm{H} 3$.

\section{System effects and practical considerations}

Based on the quantities of herbage ensiled from each sward type and the silage DMls, one hectare of a red clover-grass mixture was able to provide sufficient silage for 811 "cow feeding days", while the respective value for GS was 989 "cow feeding days". Although milk yield during the experimental period was higher with RCGS than with GS treatments $(2,220 \mathrm{~kg}$ vs. $2,103 \mathrm{~kg}$, respectively), milk fat + protein yield was higher with GS treatments (238 kg vs. $231 \mathrm{~kg}$, respectively). However, while the milk yield was driven in part by the substantially higher intakes with RCGS than with $\mathrm{GS}$ at $\mathrm{H} 1$, largely due to this being the first harvest following establishment, similar effects would not be expected to arise in subsequent years. Furthermore, limits to red clover persistence also need to be taken into account, with re-seeding of red clover swards normally being required every 3-4 yr. However, one of the main benefits of red clover inclusion in swards is the saving on inorganic $\mathrm{N}$ fertiliser, which, in this study, was estimated to be $263 \mathrm{~kg} \mathrm{~N} / \mathrm{ha}$ over the course of the season. However, as red clover swards still have a requirement for phosphates and potash, the commonly practised application of organic manures may lead to the crop being oversupplied with $\mathrm{N}$.

Furthermore, the study has clearly demonstrated the very different cow performance responses to red clover inclusion, which can arise between individual harvests within a season, especially during the first full season following establishment, when the relative proportions of the two species changed considerably over the season. Indeed, this issue is rarely identified in published studies as most have involved offering silage from a single harvest. The variability 
in silage composition between harvests also creates very practical challenges, both commercially and experimentally. For example, the very different forage CP levels with RCGS (increasing from 98 to $216 \mathrm{~g} / \mathrm{kg} \mathrm{DM}$, between $\mathrm{H} 1$ and $\mathrm{H} 3$, compared to the increase from 132 to $158 \mathrm{~g} / \mathrm{kg}$ DM for GS) create real practical difficulties in balancing the protein content of the diets offered. The use of a single concentrate type with both forages and across harvests, as was adopted in the current study, resulted in total ration protein levels being inadequate at $\mathrm{H} 1$ and excessive at $\mathrm{H} 3$. Similarly, while both swards were harvested on the same date at each of $\mathrm{H} 1-\mathrm{H} 3$ in the current study, given the different growth patterns of the swards, different harvesting dates might have been adopted if a "systems"-type study had been undertaken. However, from an experimental point of view, this would have resulted in swards being harvested and ensiled under different sets of weather conditions, confounding the responses of the sward types. Similarly, while both forage types were wilted for the same duration at each harvest, again differing periods of wilting might have been adopted if weather conditions had allowed. However, periods of rainfall during all three harvests in the current study dictated that longer periods of field wilting were not practical. This demonstrates the difficulty in achieving target DM concentrations with cloverrich swards under typical Irish weather conditions, with this being particularly evident at $\mathrm{H} 3$.

\section{Conclusions}

This study provides an insight into how the feeding and milkproducing characteristics of silage produced from a sward sown as a red clover-grass mixture changes as the season progresses. While intakes were higher and the milk yields tended to be higher with the RCGS over the entire study period, responses varied considerably between harvests, with this largely reflecting the differences in red clover proportion in the silage and the associated effects on total diet protein content and digestibility. In particular, this study demonstrated that account needs to be taken of the low $\mathrm{N}$ content of grass in the red clover-grass mixture, with these differences often ignored in studies when silage from highly fertilised grass is mixed with red clover silage to simulate silage from a mixed sward. Effects on $\mathrm{N}$ use efficiency largely reflected the differences in $\mathrm{N}$ intakes, relative to milk $\mathrm{N}$ output, with this driven largely by differences in the composition of the forages offered.

\section{Acknowledgements}

This study was funded by the Department of Agriculture, Environment and Rural Affairs (DAERA) in Northern Ireland and by AgriSearch. David Johnston was in receipt of a DAERA Postgraduate Studentship. The authors thank the staff of the Dairy Unit at the Agri-Food and Biosciences Institute for management of the experimental animals, as well as the laboratory staff for analysis of samples.

\section{References}

Bertilsson, J. and Murphy, M. 2003. Effects of feeding clover silages on feed intake, milk production and digestion in dairy cows. Grass and Forage Science 58: 309-322.

Calamiglia, S. and Stern, M.D. 1995. A three-step in vitro procedure for estimating intestinal digestion of protein in ruminants. Journal of Animal Science 73: 1459-1465.

Canfield, R., Sniffen, C. and Butler, W. 1990. Effects of excess degradable protein on postpartum reproduction and energy balance in dairy cattle. Journal of Dairy Science 73: 23422349.

Castillo, A.R., Kebreab, E., Beever, D.E. and France, J. 2000. A review of efficiency of nitrogen utilisation in lactating dairy cows and its relationship with environmental pollution. Journal of Animal and Feed Sciences 9: 1-32.

Castle, M.E. and Watson, J. 1974. Red clover silage for milk production. Journal of the British Grassland Society 29: 1 01-108.

Cheng, L., Kim, E.J., Merry, R.J. and Dewhurst, R.J. 2011. Nitrogen partitioning and isotopic fractionation in dairy cows consuming diets based on a range of contrasting forages. Journal of Dairy Science 94: 2031-2041.

Clavin, D., Crossan, P., Grant, J. and O'Kiely, P. 2017. Red clover for silage: management impacts on herbage yield, nutritive value, ensilability and persistence, and relativity to perennial ryegrass. Grass and Forage Science 72: 414-431.

Dahlin, A.S. and Stenberg, M. 2010. Transfer of $\mathrm{N}$ from red clover to perennial ryegrass in mixed stands under different cutting strategies. European Journal of Agronomy 33: 149-156.

Dale, A.J., Laidlaw, A.S., Bailey, J.S. and Mayne, C.S. 2014. Effect of dairy slurry application rate and forage type on production, soil nutrient status and nitrogen-use efficiency. Grass and Forage Science 70: 44-58.

Dewhurst, R.J. 2013. Milk production from silage: comparison of grass, legume and maize silages and their mixtures. Agricultural and Food Science 22: 57-69.

Dewhurst, R.J., Fisher, W.J., Tweed, J.K.S. and Wilkins, R.J. 2003a. Comparison of grass and legume silages for milk production. 1. Production responses with different levels of concentrate. Journal of Dairy Science 86: 2598-2611.

Dewhurst, R.J., Evans, R.T., Scollan, N.D., Moorby, J.M., Merry, R.J. and Wilkins, R.J. 2003b. Comparison of grass and legume silages for milk production. 2. In vivo and in sacco evaluations of rumen function. Journal of Dairy Science 86: 2612-2621. 
Dewhurst, R.J., Delaby, L., Moloney, A., Boland, T. and Lewis, E. 2009. Nutritive value of forage legumes used for grazing and silage. Irish Journal of Agricultural and Food Research 48: 167-187.

Dhanoa, M. 1988. On the analysis of dacron bag data for low degradability feeds. Grass and Forage Science 43: 441-444.

Edmonson, A.J., Lean, I.J., Weaver, L.D., Farver, T. and Webster, G. 1989. A body condition scoring chart for Holstein dairy cows. Journal of Dairy Science 72: 68-78.

FAWC. 1997. "Report on the Welfare of Dairy Cattle". Farm Animal Welfare Committee, Ministry of Agriculture, Food and Fisheries .

Halmemies-Beauchet-Filleau, A., Vanhatalo, A., Toivonen, V., Heikkilä, T., Lee, M. and Shingfield, K. 2012. "Effect of Replacing Grass Silage with Red Clover Silage on Rumen Lipid Metabolism and Milk Fatty Acid Composition". MTT Agrifood Research Finland, University of Helsinki, Finland, Helsinki, Finland, pages 40-41.

Halmemies-Beauchet-Filleau, A., Vanhatalo, A., Toivonen, V., Heikkilä, T., Lee, M. and Shingfield, K. 2014. Effect of replacing grass silage with red clover silage on nutrient digestion, nitrogen metabolism, and milk fat composition in lactating cows fed diets containing 60:40 forage-to-concentrate ratio. Journal of Dairy Science 97: 3761-3776.

Haynes, R. and Williams, P. 1993. Nutrient cycling and soil fertility in the grazed pasture ecosystem. Advances in Agronomy 49: 119-199.

Heinriches, J., Jones, C. and Bailey, K. 1997. Milk components: understanding the causes and importance of milk fat and protein variation in your dairy herd. Dairy \& Animal Science Fact Sheet 5: $1 \mathrm{e}-8 \mathrm{e}$.

Hynes, D., Laidlaw, S. and Ferris, C. 2018. Effect of management strategy on wilting of monocultures and mixtures of red clover and perennial ryegrass. Proceedings of the 27th General Meeting of the European Grassland Federation, Cork, Ireland, pages 249-251.

Johansen, M., Søegaard, K., Lund, P. and Weisbjerg, M.R. 2017. Digestibility and clover proportion determine milk production when silages of different grass and clover species are fed to dairy cows. Journal of Dairy Science 100: 8861-8880.

Johansen, M., Lund, P. and Weisbjerg, M.R. 2018. Feed intake and milk production in dairy cows fed different grass and legume species: a meta-analysis. Animal 12: 66-75.

Keady, T., Mayne, C. and Fitzpatrick, D. 2000. Prediction of silage feeding value from the analysis of the herbage at ensiling and effects of nitrogen fertilizer, date of harvest and additive treatment on grass silage composition. The Journal of Agricultural Science 134: 353-368

Kebreab, E., Mills, J., Crompton, L., Bannink, A., Dijkstra, J., Gerrits, W. and France, J. 2004. An integrated mathematical model to evaluate nutrient partition in dairy cattle between the animal and its environment. Animal Feed Science and Technology 112: 131-154.

King, C., McEniry, J. and O'Kiely, P. 2012. A note on the fermentation characteristics of red clover silage in response to advancing stage of maturity in the primary growth. Irish Journal of Agricultural and Food Research 51: 79-84.
Kuoppala, K., Ahvenjarvi, S., Rinne, M. and Vanhatalo, A. 2009. Effects of feeding grass or red clover silage cut at two maturity stages in dairy cows. 2. Dry matter intake and cell wall digestion kinetics. Journal of Dairy Science 92: 5634-5644.

Lee, M.R. 2014. Forage polyphenol oxidase and ruminant livestock nutrition. Frontiers in Plant Science 5: 694.

Lee, M.R.F., Winters, A.L., Scollan, N.D., Dewhurst, R.J., Theodorou, M.K. and Minchin, F.R. 2004. Plant-mediated lipolysis and proteolysis in red clover with different polyphenol oxidase activities. Journal of the Science of Food and Agriculture 84: 1639-1645.

Lee, M.R.F., Theobold, V.J., Tweed, J.K.S., Winters, A.L. and Scollan, N.D. 2009. Effect of feeding fresh or conditioned red clover on milk fatty acids and nitrogen utilization in lactating dairy cows. Journal of Dairy Science 92: 1136-1147.

McEniry, J., King, C. and O'Kiely, P. 2013. Silage fermentation characteristics of three common grassland species in response to advancing stage of maturity and additive application. Grass and Forage Science 69: 395-409.

Moorby, J.M., Lee, M.R.F., Davies, D.R., Kim, E.J., Nute, G.R., Ellis, N.M. and Scollan, N.D. 2009. Assessment of dietary ratios of red clover and grass silages on milk production and milk quality in dairy cows. Journal of Dairy Science 92: 1148-1160.

Morrison, J., Jackson, M.V. and Sparrow, P. 1980. "The Response of Perennial Ryegrass to Fertilizer Nitrogen in Relation to Climate and Soil". Report of the Joint ADAS/GRI Grassland Manuring Trial-GM. 20. Technical Report, Grassland Research Institute, Hurley, page 71 .

Moseley, G. and Jones, J.R. 1984. The physical digestion of perennial ryegrass (Lolium perenne) and white clover (Trifolium repens) in the foregut of sheep. British Journal of Nutrition $\mathbf{5 2}$ : 381-390.

Mtengeti, E.J., Wilman, D. and Mosley, G. 1996. Differences between twelve forage species in physical breakdown when eaten. Journal of Agricultural Science 126: 287-293.

Murphy, M., Åkerlind, M. and Holtenius, K. 2000. Rumen fermentation in lactating cows selected for milk fat content fed two forage to concentrate ratios with hay or silage. Journal of Dairy Science 83: 756-764.

Naadland, S.S., Steinshamn, H., Krizsan, S.J. and Randby, Å.T. 2016. Effect of replacing organic grass-clover silage from primary growth with regrowth on $\mathrm{N}$ digestion in dairy cows. Animal Feed Science and Technology 220: 57-66.

Ørskov, E. and McDonald, I. 1979. The estimation of protein degradability in the rumen from incubation measurements weighted according to rate of passage. The Journal of Agricultural Science 92: 499-503.

Park, R.S., Agnew, R.E., Gordon, F.J. and Steen, R.W.J. 1998. The use of near infrared reflectance spectroscopy (NIRS) on undried samples of grass silage to predict chemical composition and digestibility parameters. Animal Feed Science and Technology $\mathbf{7 2}$ 155-167. 
Peyraud, J., Le Gall, A. and Lüscher, A. 2009. Potential food production from forage legume-based-systems in Europe: an overview. Irish Journal of Agricultural and Food Research 48: 115-135.

Roberts, D.J., Lawson, A. and Fisher, G.E.J. 1990. A comparison of a red clover/grass sward with a grass sward plus fertilizer nitrogen under a three-cut silage regime. Proceedings of the British Grassland Society Second Research Conference British Grassland Society, Reading, United Kingdom, Session III Paper 5.

Robinson, P., Fadel, J. and Tamminga, S. 1986. Evaluation of mathematical models to describe neutral detergent residue in terms of its susceptibility to degradation in the rumen. Animal Feed Science and Technology 15: 249-271.

Smith, R.R., Taylor, N.L and Bowley, S.R. 1985. Red clover. In: "Clover Science and Technology" (ed. N.L. Taylor), ASA/CSSA/ SSSA, Madison, Wisconsin, USA, pages 457-470.

Steen, R.W.J. 1989. A comparison of soyabean, sunflower, and fish meals as protein supplements for yearling cattle offered grass silage based diets. Animal Production 48: 127-132.

Steen, R.W.J. and Mcllmoyle, W.A. 1982. An evaluation of red clover silage for beef production. Animal Production 34: 95-101.

Tamminga, S., van Straalen, M.W., Subnel, A.P.J., Meijer, R.G.N., Steg, A., Wever, C.J.G. and Blok, M.C. 1994. The Dutch protein evaluation system: the DVE/OEB system. Livestock Production Science 40: 139-155.

Theodoridou, K. and Yu, P. 2013. Effect of processing conditions on the nutritive value of canola meal and presscake. Comparison of the yellow and brown-seeded canola meal with the brown-seeded canola presscake. Journal of the Science of Food and Agriculture 9: 1986-1995.

Theodorou, M.K., Kingston-Smith, A.H., Winters, A.L., Lee, M.R.F., Minchin, F.R., Morris, P. and MacRea, J. 2006. Polyphenols and their influence on gut function and health in ruminants: a review. Environmental Chemistry Letters 4: 121-126.

Van Soest, P.J. 1976. Laboratory methods for evaluating the energy value of feedstuffs. In: "Feed and Energy Sources for Livestock" (eds. H. Swan and D. Lewis), Butterworths, London, UK, pages 83-94.

Vanhatalo, A., Gäddnäs, T. and Heikkilä, T. 2006. Microbial protein synthesis, digestion and lactation responses of cows to grass or grass-red clover silage diet supplemented with barley or oats. Agricultural and Food Science 15: 252-267.

Vanhatalo, A., Kuoppala, K., Ahvenjarvi, S. and Rinne, M. 2009. Effects of feeding grass or red clover silage cut at two maturity stages in dairy cows. 1. Nitrogen metabolism and supply of amino acids. Journal of Dairy Science 92: 5620-5633.

Varel, V.H., Nienaber, J.A. and Freetly, H.C. 1999. Conservation of nitrogen in cattle feedlot waste with urease inhibitors. Journal of Animal Science 77: 1162-1168.

Waghorn, G. 2008. Beneficial and detrimental effects of dietary condensed tannins for sustainable sheep and goat productionprogress and challenges. Animal Feed Science and Technology 147: 116-139.

Weisbjerg, M. and Soegaard, K. 2008. Feeding value of legumes and grasses at different harvest times. Biodiversity and Animal Feed: Future Challenges for Grassland Production. Grassland Science in Europe 13: 513-515.

Wilkins, R.J. and Jones, R., 2000. Alternative home-grown protein sources for ruminants in the United Kingdom. Anim Feed Sci Tech, 85: 23-32.

Wright, D., Frost, J., Patterson, D. and Kilpatrick, D. 1997. The influence of weight of ryegrass per unit area and treatment at and after mowing on rate of drying. Grass and Forage Science 52: 86-98. 